\title{
PROGRAMA JOVEM APRENDIZ: DESENVOLVENDO PROFISSIONAIS DO FUTURO
}

\author{
Latorre TAMH ${ }^{1}$, Paternes $\mathrm{KC}^{2}$ \\ 1. Assistente Administrativo responsável pela área de Gestão de Desenvolvimento de Pessoas no Instituto de Radiologia do HCFMUSP/InRad \\ 2. Assessor Técnico responsável pelo Centro de Gestão de Pessoas no Instituto de Radiologia do HCFMUSP/InRad
}

\section{Introdução}

Entendemos que o processo de aprendizagem organizacional é fundamental para o desenvolvimento do jovem que inicia suas atividades no mercado de trabalho.

A aprendizagem é um instrumento que possibilida a criação de oportunidades para o jovem, mas também gera oportunidades para as empresas que absorvem esse público. Dá ainda oportunidades às empresas de formarem mão de obra qualificada, contribuindo assim para a formação técnico-profissional(1).

\section{Objetivo}

Incluir, capacitar e promover o desenvolvimento pessoal e profissional dos jovens, proporcionando condições para que possam competir e atuar no mercado de trabalho.

\section{Materiais e Métodos}

O método utilizado para desenvolver o jovem aprendiz foi elaborado através do desenho de um programa institucional descrito abaixo. Levantamos as atividades das áreas interessadas em receber os aprendizes, após a contratação realizamos testes e vivências para definir a área que o aprendiz será direcionado, de acordo com seu perfil comportamental e habilidades demonstradas.

Realizamos a Integração no Instituto, contemplando tour para conhecer as áreas e lideranças.

Interagiram com os gestores na atividade "Gestor Sombra" que tem o objetivo de desenvolver nos jovens uma visão real do mundo do trabalho. Durante um dia por mês o jovem seguiu o Gestor escolhido em todas as atividades diárias, conheceu sua história profissional e como é sua atuação no Instituto.

Participaram da reunião "Papo Sério" que aborda temas com o objetivo de desenvolvimento dos jovens. São trabalhados aspectos técnicos, comportamentais e dinâmicas para vivência dos temas.

Receberam premiação com um par de ingressos Cinemark aqueles que apresentaram a melhor nota do mês na atividade teórica extra.

Estiveram na "Observação Técnica" onde o aprendiz escolhe duas áreas de interesse para passar meio período observando a atuação de profissional do cargo escolhido. Esta observação tem como objetivo ajudá-lo a definir a profissão que pretende exercer no futuro

Foram avaliados pelas lideranças na metade do período contratual e receberam feedback em relação a apresentação pessoal, comportamento, comunicação, atividades práticas e conhecimento para atender às recomendações da Lei da Aprendizagem(2) e será aplicada a mesma avaliação ao término do contrato para comparação do desenvolvimento.

Cumpriram treinamento em modalidade à distância das ferramentas do Pacote Office, com emissão de certificado.

\section{Resultados}

A aproximação e o acompanhamento das atividades realizadas no período de maio a dezembro de 2018 possibilitou maior engajamento dos jovens aprendizes, incentivo à participação nas ações propostas e aumento na produtividade.

É observada pela liderança mudança comportamental baseada nas orientações e experiências vivenciadas.

\section{Conclusão}

Essa metodologia trouxe maior interação entre a equipe, reforçando o relacionamento interpessoal e a autoconfiança.

Nos deu oportunidade de validarmos a metodologia, contribuindo para o desenvovimento profissional dos jovens. A conscientização e apoio das chefias também contribuiu para a implementação e aprimoramento.

\section{Referências Bibliográficas}

Lei da Aprendizagem - Lei 10.097/00

Manual da Aprendizagem elaborado pelo Ministério do Trabalho e Emprego - MTE https://www.camppinheiros.org.br/

\section{Instituto de Radiologia HCFMUSP}

